\title{
O vício capital da inveja na visão de Ramon Llull
}

\author{
The capital vice of envy in Ramon Lull's vision
}

\author{
Armando Alexandre dos Santos \\ aasantos@uol.com.br \\ Universidade do Sul de Santa Catarina
}

\begin{abstract}
Resumo: Exposição do pensamento de Ramon Llull acerca do vício capital da inveja, inserida na cultura e na espiritualidade da Idade Média, destacando, de um lado, sua conformidade com a doutrina espiritual e teológica acerca do assunto, e de outro lado sua extrema originalidade na aplicação prática dessa doutrina.
\end{abstract}

Palavras-chave: inveja, vício capital, espiritualidade medieval, literatura catalã, Ramon Llull

\begin{abstract}
Exposition of Ramon Llull's thought about the capital vice of envy, inserted in the culture and spirituality of the Middle Ages, highlighting its conformity with the spiritual and theological doctrine on the subject, and at the same time his extreme originality in the application practice of that doctrine.
\end{abstract}

Keywords: envy, capital vice, medieval spirituality, catalan literature, Ramon Llull

\section{Conceituação da inveja: pecado (ou vício) capital}

A inveja é uma paixão -ou um sentimento- que desde os mais remotos tempos sempre exerceu grande papel na História humana. Encontram-se traços dela em todas as épocas, na mitologia, na história e na literatura de todos os povos. O que caracteriza a inveja é a tristeza pelo bem alheio que não se possui. $\mathrm{O}$ invejoso se atormenta porque outro tem algo que ele queria ter, ou é alguma coisa que ele queria ser. $\mathrm{E}$, em consequência, ele se esforça para privar o outro daquele bem, ainda que não possa vir a possuí-lo, somente pelo gosto de não ver outra pessoa que a algum título o supere.

A inveja consiste na deformação de um sentimento que, em sua origem, é de si legítimo: o verdadeiro amor de cada qual por si mesmo. Esse sentimento legítimo está na origem de toda forma de progresso e aprimoramento humano, porém, quando exacerbado e envenenado pelo amor próprio, transforma-se em algo muito perigoso.

DATA PRESENTACIÓ: 21/06/2020 ACCEPTACIÓ: 04/07/2020 • PUBLICACIÓ: 10/12/2020 
Numa ótica religiosa -como a que prevalecia na Idade Média, no tempo em que viveu Ramon Llull (12321316) - a inveja é até mesmo anterior à história humana. Por ser uma paixão de natureza intelectiva, pode ser vivida e praticada por puros espíritos, sem a necessidade de intermediação dos sentidos. Assim, já antes da Criação da Humanidade podia haver inveja entre os espíritos angélicos, e foi por inveja que Lúcifer se revoltou contra Deus. A inveja do diabo em relação à obra de Deus também esteve na origem do Pecado Original, tal como afirma textualmente o Livro da Sabedoria: «Deus criou o homem imortal, e o fez à sua imagem e semelhança. Mas, por inveja do demônio, entrou no mundo a morte; e experimentam-na os que são do partido dele» (Sab, 2,23-25). O modo como a serpente tentou Eva, de acordo com o Gênesis, foi precisamente despertando nela um sentimento de inveja em relação a Deus, pois lhe assegurou que, caso comesse do fruto proibido, ela e Adão seriam «como deuses» («eritis sicut dii» -Gen, 3,5). Consumado o Pecado Original e exilado o primeiro casal para a terra, desde logo manifestou-se a inveja. Foi um sentimento de inveja que esteve na raiz do primeiro crime de morte, de Caim contra seu irmão Abel (Gen, 4,1-16). E, a partir daí, a inveja sempre exerceu seu papel nefasto ao longo dos tempos, em todas as sociedades humanas. Curiosamente, a inveja também esteve presente no processo diametralmente oposto ao do Pecado Original, ou seja, na Redenção do gênero humano, consumada por Jesus Cristo, o Filho de Deus, por meio de sua Paixão e Morte. Com efeito, a inveja foi o móvel que levou os Príncipes dos Sacerdotes israelitas a acusarem Jesus Cristo diante do tribunal de Pôncio Pilatos, fato que não passou despercebido ao próprio governador romano, que ainda tentou salvar Jesus Cristo ao propor sua soltura (como era costume ser feito, por ocasião da solenidade da Páscoa), «porque sabia que o haviam entregado por inveja» (Mt, 27,18).

São Tomás de Aquino (1225-1274), na Summa Theologiae, dedicou uma questão inteira (II-IIae, q. 36) ao estudo da inveja, colocando-a entre os vícios capitais, como contrária à caridade, ou amor ao próximo; tratou também extensamente dos vícios capitais e da inveja em Quaestiones disputatae De Malo (1982: 191-197 e 217223). Nessas obras, que marcaram profundamente o pensamento cristão até os tempos atuais, Tomás seguiu a esteira tradicional do pensamento católico, já que desdobrou e sistematizou o que ensinara, no início da Idade Média, o Papa São Gregório Magno (c. 540-604). ${ }^{1}$ Este último, desenvolvendo por sua vez, elementos fragmentários de autores anteriores, formulou com clareza a doutrina dos sete pecados capitais, que são o orgulho, a avareza, a inveja, a ira, a luxúria, a gula e a preguiça. São pecados particularmente perigosos, não porque sejam necessariamente mortais, mas porque são cabeças (daí o nome capitais) de outros pecados que atraem consigo, à maneira de séquito. No caso concreto da inveja, costuma ela abrir um cortejo de «filhas» que a acompanham e constituem -ou pelo menos podem constituir- outros tantos pecados.

O cortejo de filhas espúrias da inveja é constituído, segundo Gregório Magno e Tomás de Aquino, pela murmuração, pela detração, pela alegria com as desgraças do próximo, pela tristeza com seus sucessos e, por fim, pelo ódio (II-IIae, q. 36, a.4).

Embora as expressões pecado capital e vício capital sejam frequentemente usadas, nas obras de espiritualidade e nos sermonários antigos, como sinônimas, conceitualmente elas se distinguem. O pecado é um ato específico, enquanto o vício é o hábito do pecado, ou seja, a condição daquele cujo pecado se tornou

1 S. Gregório tratou exprofesso da inveja em três passagens dos seus comentários sobre o Livro de Jó. Na parte I tratou da inveja do diabo em relação a Deus (1849, col. 590) e da psicologia do invejoso (1849, col. 727-730). Na parte II, tratou genericamente dos vícios ou pecados capitais, de sua malícia e de sua particular forma de dinamismo (1849, col. 620-625). Uma ampla exposição do desenvolvimento da teologia moral cristã, a partir dos textos bíblicos, acerca da inveja e dos vícios capitais pode ser encontrada em Santos (2018: 41-118). 
frequente e que pelo próprio dinamismo das paixões humanas tende a se repetir e perpetuar. Cada pecado cometido torna o pecador mais vulnerável diante de novas tentações e menos resistente a elas.

O objetivo do presente artigo é estudar o pensamento de Ramon Llull a respeito da inveja. Como veremos, ele, de um lado, segue a linha geral do pensamento eclesiástico do seu tempo, reafirmando o entendimento de São Gregório Magno e coincidindo com o de São Tomás de Aquino, no sentido de que a inveja é um pecado (ou vício) capital, de particularíssima gravidade e causador de inúmeros males ao gênero humano. Mas, de outro lado, é extremamente original e inovador nos seus comentários, especificamente na aplicação prática, a casos concretos da vida humana, da doutrina assente entre os teólogos sobre a inveja. Igualmente se revela, nesses comentários, profundo conhecedor da psicologia humana, assim como dos hábitos sociais do seu tempo.

\section{Espiritualidade e originalidade de Llull, Beato por equipolência}

Antes de entrarmos no estudo do ensinamento de Ramon Llull sobre a inveja, cabe apresentar um breve resumo de como ela era vista na espiritualidade franciscana, na qual se inseriu o mestre catalão. Essa espiritualidade -que marcou profundamente a Baixa Idade Média, desde inícios do século XIII até à passagem, em data não muito determinada, para os Tempos Modernos- considerava a inveja como algo muito perigoso. Toda a visão do mundo franciscana se centrava no culto à virtude da Pobreza, prioritariamente pregado pelo fundador São Francisco de Assis (c. 1181-1226). ${ }^{2}$

Numa época em que o apego intemperante às riquezas minava profundamente a espiritualidade medieval, irrompeu Francisco, o enamorado da «Dama Pobreza», para restaurar o equilíbrio necessário. Renunciou à herança de seu pai (o opulento burguês Pietro Bernardone, próspero comerciante da cidade de Assis) e decidiu viver sem nada, levando a prática da virtude da pobreza até um radicalismo difícil de conceber. Fundou a Ordem dos Frades Menores, que em poucos anos se transformou numa das maiores da Cristandade. Fundou, com Santa Clara de Assis (c. 1193-1253), o ramo feminino da mesma Ordem. Para os leigos que viviam no mundo, mas desejavam ser fiéis ao espírito de pobreza e participar das graças e privilégios da espiritualidade franciscana, instituiu a Ordem Terceira -atualmente conhecida como Ordem Franciscana Secular- à qual pertenceu Ramon Llull.

De acordo com a pregação e o exemplo de vida de São Francisco, a posse de bens e, sobretudo, o apego a eles era o maior mal a ser evitado, o maior escolho no caminho da perfeição. Bens, no caso, eram imediatamente aqueles materiais, os de raiz, as riquezas, o dinheiro. Mas também deviam ser evitados os bens imateriais, como a honra, o prestígio, a consideração, a vanglória, pois se opunham à perfeição da pobreza e igualmente podiam desviar do amor de Deus e do próximo. No seu entusiasmo pela pobreza, num momento inicial de radicalismo que depois compreendeu ser excessivo, Francisco chegou a desejar que seus frades fossem ignorantes, porque até o conhecimento e a cultura lhe pareciam formas de apropriação indevidas, contrárias à prática suprema da pobreza e do despojamento. Só mais tarde compreendeu, em face das circunstâncias concretas, que esse ideal podia ser sublime, mas não era razoável e tampouco correspondia às necessidades da Igreja, que precisava de teólogos, de doutores, de pregadores da palavra de Deus. Mesmo depois da morte

2 Sobre a vida de São Francisco de Assis, ver San Francisco de Asís. Escritos. Biografías. Documentos de la época (1993). Sobre a espiritualidade franciscana, Iriarte (1985: 151-157). Uma tentativa de interpretação da figura e do papel histórico do fundador dos franciscanos pode ser encontrada em Le Goff (2001). No mesmo sentido, Vauchez (1994: 245-263).

SCRIPTA, Revista internacional de literatura i cultura medieval i moderna, núm. 16 / desembre 2020 /pp. 1-13 
de São Francisco, ocorrida em 1226, durante algumas décadas ainda persistiu entre os franciscanos certa tendência a ver com maus olhos os estudos, por julgá-los contrários ao verdadeiro espírito do Poverello de Assis. Em 1260, no Capítulo geral da Ordem realizado em Narbona, o então superior geral São Boaventura (1218-1274) precisou fazer uma defesa formal dos estudos, sustentando que eles eram um eficiente meio de amar a Deus e fazer Deus amado pelos outros (Ullmann 2000: 227).

Toda a espiritualidade franciscana se centra na compreensão de que os bens materiais ou imateriais, quando desviados da sua reta finalidade, afastam os homens, e sobretudo os religiosos, da verdadeira caridade e, portanto, de Deus.

É dentro dessa espiritualidade que se deve entender e interpretar a surpreendente personalidade de Ramón Llull (1232-1316), estrela de primeiríssima grandeza da cultura e da língua catalã, venerado como Beato na Catalunha e também nas casas mantidas por religiosos franciscanos de todo o mundo. É considerado um dos cinco grandes luminares do pensamento franciscano medieval -a par com São Boaventura, Duns Scoto, Rogério Bacon e Santo Antônio de Lisboa- e sua influência marcou profundamente o pensamento filosófico europeu, mesmo fora dos círculos estritamente religiosos. ${ }^{3}$

Na encíclica Rerum Orientalium, datada de 8 de setembro de 1928, o Papa Pio XI se referiu ao filósofo catalão em termos altamente elogiosos, embora sem lhe atribuir o título de Beato:

Il celebre Raimondo Lullo, uomo di straordinaria erudizione e pietà, molte cose e con più vivace ardore, proprio dell'indole sua, chiese ai Nostri predecessori Celestino V e Bonifacio VIII, e ne ottenne parecchie, per quei tempi assai ardite, circa il modo di promuovere gli affari e gli studi Orientali; il designare, fra gli stessi Cardinali, uno che presiedesse a siffatti studi; infine del modo di intraprendere frequenti sacre missioni sia tra i Tartari, i Saraceni ed altri infedeli, sia fra gli scismatici, da ricondurre all'unità della Chiesa

De fato, Ramon Llull nunca foi beatificado formalmente, mas seu culto como Beato foi e ainda é regularmente praticado na Igreja Católica, no âmbito dos religiosos franciscanos e em toda a região da Catalunha. Em termos mais precisos, pode-se-lhe atribuir o que se chama uma «beatificação equipolente». As beatificações formais, que seguem um procedimento rigoroso estabelecido na primeira metade do século XVII pelo Papa Urbano VII (+1634), e um tanto alterado, em 1983, pelo Papa João Paulo II, são realizadas após longo e minucioso processo conduzido inicialmente na circunscrição eclesiástica do candidato e depois em Roma, na alçada da Sagrada Congregação dos Ritos (e mais recentemente da Congregação das Causas dos Santos). As beatificações equipolentes são um reconhecimento, pela Santa Sé, do culto solidamente estabelecido, desde tempos imemoriais, a um determinado beato (Roberti-Palazzini(1957, verbete «Beatificazione e canonizzazione»). No Martirológio Franciscano oficialmente aprovado para uso dos Frades Menores, das Religiosas Clarissas e dos membros da Ordem Terceira de São Francisco (atual Ordem Franciscana Secular), composto em 1653 -já depois da regulamentação fixada para as canonizações e beatificações por Urbano VIII- e reeditada com todas as aprovações eclesiásticas em 1939, lê-se textualmente, entre as celebrações do dia 29 de junho (tertio calendas julii): «Palmae, in Majorica Insula, BEATI RAYMUNDI LULLI Martyris ex

3 Sobre a importância de Llull no pensamento franciscano, ver Gemelli (1947: 56-65) e Merino (1993: 267-283). Sua biografia, com uma análise pormenorizada de sua extensa obra e da influência que teve na Filosofia dos últimos séculos, pode ser encontrada em Vacant et alii (1913, verbete «Lulle Raymond»). 
Tertio Ordine, doctrina et scriptis, necnon dilatandae fidei studio insignis, in cujus honorem Leo Decimus Officium ac Missam celebrari concessit». No Martirologio romano promulgado pelo Papa João Paulo II, consta oficialmente, no dia 29 de Junho, a celebração litúrgica do «beato Raimondo Lullo, religioso del Terz’Ordine di San Francesco e martire, uomo di grande cultura e di illuminata dottrina» 2004: 502). O Calendário Litúrgico Franciscano Universal também registra, no dia 30 de junho, a recordação facultativa da memória do «BemAventurado Raimundo Lulo, Mártir, da Ordem Franciscana Secular (2016: 11 e 61). No mesmo sentido, também a Liturgia das Horas - Próprio para a Familia Franciscana Portuguesa (edição de 1976) recorda em breves palavras a vida e a morte de Ramon Llull:

\begin{abstract}
30 de Junho - B. RAIMUNDO LULO, mártir, da Ordem Terceira. Raimundo Lulo nasceu cerca de 1235, na cidade de Palma da ilha de Maiorca nas Baleares. Dando de mão a tudo o que é da terra, alistou-se na Terceira Ordem Franciscana e, inflamado do zelo das almas, tratou da fundação de um colégio, na pátria, para a conveniente formação de missionários. Escreveu sobre quase todas as disciplinas humanas, e foi chamado Doutor lluminado. Numa viagem que fez a Bugia na África, foi ali preso, encarcerado e, depois de muitos maus tratos, por sentença foi apedrejado. Recolhido, exânime, por um navio de cristãos, expirou quando já aportava à ilha de Maiorca, em 29 de Junho de 1315.
\end{abstract}

\title{
3. O pensamento de Llull sobre a inveja
}

Em sua obra extensa e diversificada, são numerosas as referências de Llull à inveja. Alguns destaques devem ser feitos, a esse respeito, para complementar e enriquecer o pensamento geral da teologia moral de seu tempo, consubstanciado e quase oficializado na teologia tomista. Embora menos sistematizados em seu método expositivo do que os do Aquinate, os escritos lulianos sobre a inveja permitem uma visão mais ajustada no espaço e no tempo, já que Llull foi casado, teve filhos e participou intensamente, na sua juventude, da vida social e mundana do tempo, além de ter exercido cargos de relevo na corte de Jaime I, o Conquistador, rei de Aragão -o que lhe confere um conhecimento prático e quase experimental de costumes e práticas sociais que São Tomás, que ingressou na vida religiosa quase adolescente, jamais conheceu por si mesmo.

\subsection{L'Arbre de ciència}

Uma das principais e mais extensas obras de Llull foi L'Arbre de ciència, verdadeira enciclopédia redigida no biênio 1295-1296 em latim, e logo vertida para o catalão. Nela, todos os conhecimentos humanos são compendiados em 16 capítulos, cada um dos quais figurativamente representado por uma árvore com todos os seus elementos constitutivos; as raízes são os fundamentos de cada ciência; o tronco é a sua estrutura principal, os galhos são os gêneros, as folhas são as espécies, os frutos são as particularizações dentro de cada espécie.

Na segunda parte da Árvore da Ciência se insere a Árvore Moral, na qual, depois de apontar as raízes dos vícios, descreve-os à maneira de sete galhos de uma árvore. Correspondem precisamente aos vícios capitais, conforme os entendia a tradição eclesiástica. Um dos braços é constituído pela inveja:

III. Dos braços da árvore viciosa (...) 6. Da Inveja

A inveja é o pecado contrário à caridade e à comunidade.

A inveja é contra a caridade porque os homens invejosos desejam ter os bens dos outros contra a justiça e a esperança, e quando não podem tê-los consideram as formas, e é onde nascem as traições, as mentiras e os enganos, os latrocínios e muitos outros males para que 
possam ter aqueles bens. Por isso, a inveja é um pecado muito grave, pois com o mal faz os homens considerarem ter os bens contrários aos males.

A inveja é contra a caridade comum, isto é, contra a caridade de Deus, que dá os bens comuns aos homens, como o fogo, que dá o calor comum às plantas nas quais tem senhorio, e ainda às plantas, que são senhoreadas pelos outros elementos. A inveja é também contra a caridade comum da fraternidade e dos bens naturais, e por isso, os homens invejosos não recorrem aos bens gerais, somente aos especiais, que desejam ter contra seus próximos.

Nesse trecho, Llull aponta muito bem o caráter profundamente perverso da inveja e realça como ela contraria a virtude da caridade, duplamente entendida, ou seja, o amor a Deus e o amor ao próximo. Até aí, seu pensamento está inteiramente dentro da tradição eclesiástica, sem nada de inovador. O que chama a atenção de quem o analisa, entretanto, é que Llull parece ter tido um discernimento muito mais vivo do que outros autores, do dinamismo peculiar da inveja, enquanto ativador e motivador de vários outros vícios capitais. Se São Gregório Magno tratou da inveja como agente da ira e São Tomás tratou genericamente de como um vício pode abrir as portas aos demais, Llull foi bem mais concreto e incisivo ao apontar como isso se dá na prática. Por exemplo, ao falar da luxúria, que constitui um dos sete braços da árvore dos vícios, mostra-a como potencial ativadora da inveja:

\begin{abstract}
A luxúria é ainda contra a sanidade, porque através dos prazeres que dá ela destrói a Árvore Vegetal, e é também contra as riquezas que o homem junta, dispondo a inveja, o engano, a traição e muitos outros males que se transformam em ato. E disso temos experiência, pois acontecem grandes males aos homens luxuriosos por causa das fêmeas, e a muitos outros por causa deles.
\end{abstract}

Também ao falar do orgulho, indica sua relação à maneira de causa e efeito, para com a inveja:

\begin{abstract}
O orgulho faz esquecer as menoridades naturais das quais o homem veio, e faz considerar as maioridades que Deus dá sob a condição de que com elas os homens sejam humildes e vestidos com os hábitos da virtude, e para que com elas, eles façam honra a Deus e a seu próximo. Por isso, os homens orgulhosos não desejam ter par nem amar uns aos outros, fazem coisas com as quais estão sujeitos à servidão de suas faltas, e têm inveja dos bens dos humildes, que se elevam com sua humildade às perfeições que Deus dá. Por isso, os homens orgulhosos são invejosos e vestidos com a acídia, razão pela qual dizem coisas más, e são irados quando não podem ser honrados nas coisas elevadas, coisas das quais o orgulho os desce para as coisas baixas que estão sob os pés dos humildes, que com sua humildade se elevam às alturas de onde os homens orgulhosos caíram. Por isso, por causa do orgulho acontecem as guerras e os sofrimentos, as iras, as tristezas e pobrezas, e muitos outros males que seriam longos de contar e dos quais não vale a pena dizer, pois deles temos experiência.
\end{abstract}

É curioso que, ao apontar o orgulho (ou soberba) como pecado capital, Llull faz eco à tradição anterior a São Gregório e se afasta deste, que ensinou não ser a soberba (sinônimo perfeito de orgulho) um dos pecados capitais, mas um pecado especial ainda mais grave que os pecados capitais, dos quais é raiz. É também curiosa a menção ao fato de os invejosos serem «vestidos com a acídia». Ao tratar desta última, que igualmente aponta como pecado capital e um dos braços da árvore dos vícios, assim a define: «A acídia é o vício pelo qual os homens têm preguiça de fazer o bem, prazer com o mal dos outros e tristeza dos seus bens.» Note-se que o prazer com o mal alheio e a tristeza com os sucessos do próximo são precisamente duas das consequências da inveja apontadas por São Gregório Magno. 


\subsection{Doctrina Pueril}

No livro pedagógico Doctrina Pueril, escrito por Llull entre 1274 e 1276, o vício capital da inveja é exposto mais extensamente, e tem sua maldade intrínseca denunciada de modo veemente. Tal obra é um dos muitos testemunhos que demonstram a preocupação que havia, na Idade Média, com a educação infantil, contrariamente ao que ainda se ensina em obras de divulgação e em manuais escolares. Nesse livro, não somente a doutrina religiosa, mas também conhecimentos úteis de natureza geral são apresentadas em linguagem acessível aos meninos da época, de modo perfeitamente estruturado, ao longo de cem capítulos que enchem quase cem páginas de texto impresso. São sucessivamente ensinados os artigos do Credo, os dez Mandamentos, os sete Sacramentos da Igreja, os sete dons do Espírito Santo, as oito bem-aventuranças, as sete alegrias da Virgem Maria, as sete principais virtudes cuja prática leva o homem ao Paraíso, os sete vícios ou pecados capitais pelos quais uma alma se perde, os vários sistemas legislativos que regem a vida dos homens, e as sete artes; o livro é concluído com um conjunto de vinte capítulos destinados à exposição de matérias diversas.

No capítulo LXV o tema da inveja é tratado mais genericamente, entre os sete pecados capitais, enquanto nos capítulos XXI e XXII é tratado de modo mais específico e em sua aplicação concreta, no âmbito de dois mandamentos do Decálogo, que proíbem maus desejos em relação à mulher e aos bens do próximo.

Vejamos, em primeiro lugar, a doutrina exposta sobre o vício capital da inveja:

LXV. Da Inveja

1. A inveja é desejar bens de outros sem meritória possessão. Assim, guarda-te desse vício, filho, tanto quanto possas, de tal maneira que não mereças estar possuído pelos demônios no fogo perpétuo.

2. Invejar bens de outros é pecado mortal, pelo qual a alma invejosa morre na ira de Deus, a qual ira faz viver a alma invejosa em morte de pena que não tem fim, na qual morte, a alma mesquinha deseja o que nunca terá.

3. Assim como através das palavras o homem tem conhecimento do que a alma deseja e entende, pela inveja e pelos outros pecados, o homem tem conhecimento neste mundo das penas infernais. Porque assim como o homem invejoso deseja o que não tem, e não faz para que o tenha sem dano de seu próximo, todos os danados infernais invejaram a celestial glória dos bens aventurados de Glória, não para que tivessem Glória, mas para que Deus tomasse a glória dos santos de Glória e desse a eles o que não mereciam.

4. De acordo com o corpo natural e com o que contam os filósofos, a forma é a demonstração da matéria. Logo, assim como a matéria é demonstrada pela forma, de acordo com a qualidade dos pecados mortais é demonstrada a pena infernal. Por isso, Deus ordenou que aqueles que usam o pecado conheçam em seu pecado a pena que está disposta neste pecado.

5. A inveja é contra a caridade, a esperança, a justiça e contra as outras virtudes. Assim, como o homem merece ter os bens corporais por ser amante das virtudes, se, por invejar, o homem pudesse ter os bens temporais, por ter virtude o homem não deveria possuir o que Deus dá somente para servir o homem. Logo, como isso é o contrário, o homem invejoso não é digno de ser possuidor de nenhum bem, para significar que os danados não têm nenhuma bemaventurança.

6. O homem invejoso não recebe graças de Deus. E se fosse outro Deus, ele acreditaria Nele, se isso the proporcionasse aquilo que inveja, e renegaria o Deus que o criou. Por isso, os homens invejosos são impacientes e desamam a Deus, quando não lhes dá alguns bens, mas se Deus lhes desse alguns bens temporais, amá-Lo-iam mais pelo que lhes foi dado que pela nobreza e bondade que Deus tem em Si mesmo.

7. O invejoso toma e não dá, destrói, mata e não perdoa. E o homem invejoso não está sem tristeza, ânsia, falsidade e engano, e é mais próprio à traição que outro homem. Filho, como a inveja tem tanto mal em si, não sejas invejoso, se desejas estar na bem-aventurança celestial com os anjos de Deus.

SCRIPTA, Revista internacional de literatura i cultura medieval i moderna, núm. 16 / desembre 2020 /pp. 1-13 


\section{Armando Alexandre dos Santos. O vício capital da inveja na visão de Ramon Llull}

Esse trecho, ademais de baseado e encadeado em lógica perfeita, também patenteia o profundo conhecimento da psicologia humana que tinha seu autor. É original, expressiva e de grande força persuasiva a ideia de que os invejosos, condenados a jamais alcançar os bens alheios aos quais tanto e tão criminosamente aspiram, já tenham nesta vida uma prelibação dos castigos eternos da vida futura. Essa como que antecipação dos castigos eternos já nesta vida se dá não só com os invejosos, mas também, como mostra nos tópicos 3 e 4, mutatis mutandis com outros que cometem outros pecados. O caráter mortalmente pecaminoso da inveja, afirmado nos tópicos 1 e 2, é realçado nos tópicos 5 e 6: a inveja, por se opor frontalmente à caridade, mata de modo irremediável o amor de Deus e do próximo; com isso, são anulados de todo os méritos que a pessoa eventualmente tinha antes adquirido, e ela se torna incapaz de ter merecimento até mesmo das obras boas que eventualmente continue fazendo. O caráter inflexível, inclemente e autopunitivo da inveja é, no tópico 7, resumido em frase lapidar: «O invejoso toma e não dá, destrói, mata e não perdoa». A melancolia, o desassossego, a falsidade e a tendência à traição são, nesse mesmo tópico, a justo título apontadas como companheiras inseparáveis do invejoso, que jamais estará «na bem-aventurança celestial com os anjos de Deus». No tópico 6, quando afirma que «o homem invejoso não recebe graças de Deus», claro está que se refere a graças eficazes, já que as graças suficientes nunca faltam a ninguém, nem mesmo ao pior dos pecadores. Essa pequenina ressalva, que de tão óbvia nem ocorreu a Llull fazer, é entretanto indispensável para assegurar a perfeita ortodoxia teológica do texto.

Da mesma forma que na Árvore da Ciência, também neste livro dedicado à educação de seu filho Llull relaciona de modo particularmente vivo -e, acrescente-se, inovador- a inveja a outros vícios capitais. Ao falar da avareza, por exemplo, registra que os avarentos têm como um dos seus castigos, ainda nesta vida, a incômoda companhia dos invejosos: «7. Se muitos vermes se acomodam a muitas carnes, ao homem avaro se acomodam muitos homens invejosos, muitos caluniadores e muitos inimigos. Sabes por quê? Porque quando possuem muitas riquezas, não as utilizam, nem para si nem para outros.» Quando exprobra a acídia, estende o sentido desse vício quase ao ponto de tomá-lo como sinônimo da inveja: «A acídia é a tristeza da alma, agravada pelo bem de seu próximo. O demônio teve acídia no bem que Deus deu ao nosso pai Adão e à nossa mãe Senhora Eva no Paraíso terreno. Por isso, aconselhou que comessem o fruto, pelo qual Adão e Eva estiveram na ira de Deus». Ao falar do orgulho, causador da inveja, de tal modo tem o foco de sua atenção no efeito que quase o identifica com a causa:

Da Soberba: (...) 6. Neste mundo, o homem orgulhoso segue a maneira que os demônios tiveram quando foram criados anjos, pois o homem pobre orgulhoso deseja ser igual ao rico homem em riqueza e honramento, e quanto mais elevado àquela riqueza e àquele honramento, menos preza aquele que lhe é igual, desejando estar acima dele em nobreza e em riqueza e igual ao outro homem que lhe está acima em riqueza e honramento. E assim não pensa em outra coisa, mas somente no desejo de se elevar, e menosprezar seu igual. Por isso, tais homens são semelhantes aos demônios, que menosprezaram os anjos benignos, quando desejaram ser mais nobres que eles e quando desejaram ser semelhantes a Deus.

Ao nono mandamento do Decálogo (Não cobiçar a mulher do próximo) é dedicado o capítulo XXI:

XXI. Não invejarás a mulher de teu próximo

1. A inveja é desejar com tristeza outros bens. Por isso, filho, Nosso Senhor Deus fez um mandamento para que o homem não tenha inveja da mulher do próximo, porque a tristeza no desejo da alma cega os olhos do entendimento.

2. Amável filho, todo homem é próximo ao outro na natureza. E como é um mandamento

SCRIPTA, Revista internacional de literatura i cultura medieval i moderna, núm. 16 / desembre 2020 /pp. 1-13 
expresso que o homem ame a seu próximo tanto quanto a si mesmo, filho, o Deus da Glória fez um mandamento que nenhum homem cobice a mulher do próximo, e neste mandamento está significado outro mandamento, isto é, que tenhas amor a teu próximo e a ti mesmo.

3. Filho, invejar a mulher de teu próximo é menosprezar e desamar teu próximo, e é menosprezar tua mulher e os parentes de tua mulher. E como Nosso Senhor Deus deseja que o homem não tenha menosprezo daquela criatura que lhe é semelhante em natureza e deseja que o homem saiba que em sua mulher existe a mesma coisa que existe na mulher de seu próximo ao dar o deleite carnal, Deus ordenou que tu não tenhas inveja da mulher de teu próximo.

4. Amável filho, para que sejas obediente aos mandamentos de Deus e não sejas invejoso, relembra a sujeira que podes entender, e compreende quão grave coisa seria se [outr]o homem desejasse tua mulher e a desordenasse da ordem do matrimônio. Pensa, também, se por tão grande sujeira é coisa conveniente perderes o amor e a glória de Deus e teres o tormento no fogo perdurável.

5. Filho, se tu fosses mais nobre que tudo o que Deus te deu, tu não serias criado. Logo, como tu és criatura que foi criada do nada e retornarias ao nada se Deus levasse tua graça, filho, entende que Deus te fez mandamento que não sejas invejoso para significar que tu és criatura criada por Nosso Senhor Deus.

No modo como aborda o nono mandamento, mais uma vez manifesta Llull sua originalidade. Enquanto o comum dos moralistas costuma analisar esse mandamento do ponto de vista estritamente sexual -ou seja, ressaltando a proibição de pecados sexuais por meio de pensamentos ou desejos consentidos em relação a cônjuge alheio- Llull não ignora o aspecto sexual, mas prefere apontar na inveja e na ofensa à dignidade do próximo a principal malícia do pecado contra esse mandamento. Mais ainda se mostra original quando inclui na designação de «próximo» não apenas o marido da mulher desejada, mas ela própria e a respectiva parentela; todos esses próximos também têm sua dignidade atingida e violada pelo desejo sexual consentido, ainda que ocultamente e sem qualquer manifestação externa. É uma visão muito ampla e abrangente desse mandamento, sem dúvida.

Por fim, ao décimo e último mandamento consagra Llull o capítulo XXII:

XXII. Não terás inveja dos bens de teu próximo

1. Sabes, filho, por que Deus, que é completo de todos os bens, fez um mandamento para que não tenhas inveja dos bens de teu próximo? Para que o homem tenha esperança em Deus, que dá ao homem bens semelhantes àqueles que deu a seu próximo.

2. Filho, não invejes os bens de teu próximo, porque Deus os deu e quis que ele os tivesse. Pois se Deus quisesse, poderia ter te dado aqueles mesmos bens. Logo, se tu desejas ter o que Deus não desejou te dar, então fazes de teu desejo o contrário da vontade de Deus.

3. Filho, não tenhas inveja de outros bens, porque se tiveres, não saberás se existirá uma hora de tempo para possuí-los. E nem se todos os bens temporais deste mundo fossem teus poderiam dar o cumprimento da vontade de tua alma.

4. Filho, os bens deste mundo não são desejáveis por eles mesmos, pelo contrário, são para servir a Deus. Logo, se tu invejas os bens do teu próximo, o teu desejo existe para servir a ti mesmo contra a vontade de Deus.

5. Filho, não invejes os bens de teu próximo, porque ele é o dono, e nestes bens que tu vês existe falta, pois eles são corruptíveis e são possuídos com labor, trabalho e temor.

6. Filho, os demônios caíram do céu por inveja, pois invejaram a glória de Deus. Logo, como tu amas elevar-te na glória que os demônios foram expulsos, a inveja que tens é contrária à tua elevação.

7. Filho, prega a pobreza dos bens temporais que Nosso Senhor Jesus Cristo, Nossa Senhora Santa Maria e os apóstolos tiveram neste mundo e te admoesta para que não sejas invejoso dos bens deste mundo, pois se Nosso Senhor Deus não quis ter, muitos não poderiam ter e muitos não poderiam dar a Nossa Senhora que tanto ama, e aos apóstolos e a outros Seus que tanta pena suportaram neste mundo por Seu amor. 
8. Quanto maiores forem tuas riquezas, filho, mais serás culpado caso não faças o bem que puderes, e serás obrigado a ouvir a cruel sentença de Deus.

9. Se com os bens que tu tens não fazes tanta bondade quanto podes, por que tens inveja dos bens que não tens e por que a inveja te faz amar mais o tesouro de teu próximo, que não é tão semelhante a ti quanto teu próximo?

10. Filho, considera as grandes faltas que fazem os homens invejosos, pois a inveja faz o homem ser avaro, falso, mentiroso, traidor e enganador, e a inveja faz os homens dizerem falsamente uma maldade e os faz se desesperar da misericórdia de Deus.

É muito denso, ademais de original, o pensamento luliano exposto nesse capítulo. Nele se sucedem em carga cerrada, os argumentos teológicos, filosóficos, jurídicos e psicológicos. Quem cobiça -ou inveja, como prefere designar Llull- os bens alheios peca contra a vontade e a sabedoria de Deus, que na ordenação geral da sociedade quis distribuir desigualmente os bens materiais; se Deus quis que determinado bem fosse de outra pessoa, como invejar essa coisa sem se pretender mais sábio que o próprio Deus? A esse raciocínio, implicitamente contido no tópico 2, outros se acrescentam, ainda no campo teológico: os bens materiais não são um fim em si, mas um meio para o serviço de Deus; pretender dispô-los de modo diferente de como Deus os dispôs não é sábio nem é justo (tópico 4); quem procede dessa forma imita os diabos que por inveja se revoltaram contra Deus e por isso foram condenados (tópico 6). Do ponto de vista psicológico, é também insano desejar bens que nunca serão capazes de saciar, pois quem anseia por eles como a fim último jamais se sentirá plenamente atendido e jamais alcançará a satisfação total (tópico 3). É também contra a justiça pretender um bem do qual o outro é legítimo dono, muitas vezes tendo-o adquirido com trabalho e esforço (tópico 5). Ademais, ter muitos bens aumenta a responsabilidade de quem os possui; é, pois, imprudente alguém querer ter mais do que Deus the deu, porque se arrisca a fazer mau uso do que não lhe competia; esse argumento, muito forte do ponto de vista psicológico, está contido nos tópicos 8 e 9 . O ideal franciscano da pobreza, sempre muito presente na espiritualidade de Llull, é manifestado no tópico 7; desejar os bens alheios contraria a virtude da pobreza, da qual Jesus Cristo, a Virgem Maria e os apóstolos foram grandes exemplos. Por fim, para remate, são lembradas as graves consequências de ordem moral, do pecado de inveja: avareza, mentiras, traições, enganos, perda da esperança na misericórdia divina.

\subsection{Fèlix o el Libre de meravelles}

O mesmo desejo de condensar e vulgarizar todo o conhecimento humano em uma obra de caráter enciclopédico Llull demonstrou ao redigir, em 1288-1289, Fèlix o el Libre de meravelles. Trata-se de um livro ficcional com algo de fantástico, no qual o protagonista Félix é enviado por seu pai a percorrer o mundo e apreciar as maravilhas que nele colocou o Criador. Dividido em dez partes, nele se expõem noções teológicas, filosóficas, cosmológicas, morais etc. Entre as noções morais, é largamente exposto o ensinamento da Igreja acerca dos pecados, e entre estes o dos pecados capitais. O estilo é muito leve, com inúmeras historietas e exempla no entremeio e utiliza recursos literários fantasiosos que somente no século XX se tornariam habituais. É, desse ponto de vista, obra extraordinariamente pioneira.

No livro VIII, capítulo 74, aparece a inveja, contraposta à virtude da continência. A palavra «continência» -esclareça-se desde logo- não tem sentido unívoco. Em sentido amplo e menos preciso, significa a firmeza da vontade e da razão para que o homem se abstenha de todo e qualquer ato ilícito. Em sentido mais estrito, significa a resistência oposta, em obediência à razão, contra as paixões veementes que tendem a dominar a razão e se impor à vontade humana. Entre estas paixões, as mais veementes são as do tato e do paladar, 


\section{Armando Alexandre dos Santos. O vício capital da inveja na visão de Ramon Llull}

de modo que a palavra continência se aplica ainda mais estritamente em matéria de sexualidade e gula. $\mathrm{Na}$ linguagem moderna, tende-se a usar a palavra continência quase exclusivamente no tocante à sexualidade, significando a firmeza racional de resistir aos assaltos desordenados do prazer venéreo ${ }^{4}$. É no sentido mais amplo, obviamente, que Llull a entende no capítulo citado:

\section{Da Continência e da Inveja}

- A continência é a moderação do desejo da exuberância de comidas, e é contrária à inveja, vício mortal, onde o desejo humano deseja injuriosamente contra o cumprimento da continência.

- Amável filho, disse o eremita, a inveja pode ser maior no homem rico que no homem pobre, e o mesmo ocorre com a continência, porque em maior vício está o homem rico se tem inveja e não tem satisfação com o que Deus lhe deu, o que não existe no homem pobre dos bens temporais.

Félix se maravilhou muito que a continência pudesse ser maior no homem rico que no homem pobre, porque lhe parecia que o homem pobre devesse estar mais agradecido se está satisfeito tendo pouco que o homem rico tendo muito. O eremita percebeu que Félix se maravilhava com o que havia dito, e lhe disse estas palavras:

- Filho, disse o eremita, todos os bens e os cumprimentos que existem e podem existir no homem, todos são de Deus. E são maiores, melhores e mais nobres quanto mais são semelhantes aos bens e cumprimentos de Deus. Logo, quando acontece de a continência estar no homem rico que é humilde e serve a Deus com toda a sua riqueza, ele pode fazer melhores obras que o homem pobre dos bens temporais. Se isso não fosse assim, seria falsa a palavra que o rei disse a um eremita.

- E como foi esta coisa, senhor?, perguntou Félix.

- Um rei e muitos cavaleiros passavam por um deserto. Naquele deserto estava um eremita, que quis saber do rei se ele era um homem justo e se estava satisfeito com a riqueza que Deus lhe dera. Aquele eremita perguntou ao rei se podia vencer a inveja com uma grande riqueza. O rei respondeu que o desejo humano é mais forte quando vence a inveja na grandeza que quando a vence na pequenez. Conforme as palavras do rei, o eremita entendeu que ele não era invejoso, que vencia a inveja com toda a sua riqueza, e tinha continência em amar, servir e honrar a Deus. O eremita teve muito prazer com o comportamento do rei, e maravilhou-se como no mundo não havia tantos quanto ele.

O eremita disse a Félix que havia um camponês pobre que tinha uma vinha próxima do campo de um cavaleiro muito rico e poderoso:

- Aquele camponês tinha inveja do campo daquele cavaleiro e o cavaleiro tinha inveja da vinha do camponês. Aconteceu que ambos foram se confessar com um frade, e cada um confessou seu pecado. O frade deu maior penitência a camponês que ao cavaleiro, porque o cavaleiro opunha-se à inveja mais fortemente que o camponês, já que não desejava usar seu poder contra o camponês, pois poderia tomar a vinha se assim o desejasse.

- A inveja existe contra a esperança, a justiça, a caridade, a fortaleza, a temperança, e concorda com todos os contrários dessas virtudes contra a continência, que tem concordância com todas essas virtudes e contrariedade com o contrário dessas virtudes. Logo, quando acontece de a inveja se multiplicar, neste momento multiplicam-se os contrários das virtudes. E quando a continência se multiplica, multiplicam-se também os contrários dos vícios.

Félix ouvia o que o eremita dizia da multiplicação da inveja e da continência, e disse a ele que se maravilhava como a inveja está tão multiplicada neste mundo, e a continência existe no mundo em tão pouca quantidade, pois as virtudes que têm alguma semelhança com Deus deveriam existir em maior grandeza que os vícios, que não têm nenhuma semelhança com Deus.

Difícil foi a questão que Félix fez ao eremita. Maravilhou-se o eremita como Félix lhe fizera tão grave questão, e esteve muito tempo em consideração antes de saber responder. Enquanto considerava por tanto tempo, o eremita disse a Félix estas palavras:

- Em uma cidade estavam um rei e um bispo. Eles eram viciosos, invejosos e de má vida. Os

4 Sobre a continência e seu oposto, a incontinência, São Tomás de Aquino tratou na Summa Theologiae, II-IIae, qu. 155 e 156. Sobre os sentidos da palavra continência, ver Aniz (Introdução à questão 155 do Tratado da Temperança, in Suma Teológica de Santo Tomás de Aquino - tomo X: 241-243). 
homens daquela cidade tinham mau exemplo da má vida do rei e do bispo, mas tinham pior exemplo do bispo que do rei, porque como o ofício de bispo é mais perto da semelhança de Deus que o de rei, a semelhança do bispo estava em maior contrariedade do bem que a semelhança do rei.

Félix entendeu a solução da questão, e disse que se maravilhava da imensa grandeza que a inveja tem no padre invejoso, porque Deus não suporta que a inveja possa ser maior no clérigo que no leigo, já que o clérigo é mais apropriado a servir a Deus que o leigo.

- Filho, disse o eremita, um cavaleiro tinha dois escudeiros. Com um escudeiro se aconselhava e dizia seus segredos, e aquele escudeiro pensava sobre a pessoa do cavaleiro; o outro escudeiro pensava a respeito do cavalo do cavaleiro. Ambos os escudeiros enganaram e traíram o cavaleiro, e o escudeiro que era mais íntimo de seu senhor que o outro sofreu um tormento maior e uma morte pior que o outro.

- Era uma vez um bispo que tinha um sobrinho que muito amava. Aquele bispo tinha um castelo belo e muito rico em seu bispado, e tinha inveja daquele castelo que era seu, pois o invejava porque desejava que fosse de seu sobrinho. ${ }^{5} \mathrm{O}$ príncipe daquela terra também invejava aquele castelo, e foi feita a questão de quem tinha mais inveja, o bispo ou o rei.

- A Inveja e a Continência se encontraram: «Inveja», disse a Continência, «por que me perseguis? Como não lembrais de quão pouco tem visto o pastor que invejava as ovelhas de seu senhor que tinha sob seu comando? O pastor matou o senhor das ovelhas para que elas fossem suas. Após ter matado seu senhor e possuído somente um dia as ovelhas, ele foi acusado de traição e, no dia seguinte, julgado à morte e enforcado». "Continência», disse a Inveja, «Por que vós vos opondes a mim, se vedes que neste mundo sou mais amada, mais honrada, e tenho mais amantes que vós? Por que não lembrais que eu existia em um rei muito nobre e poderoso que tomou uma bela mulher que um cavaleiro tinha e vós, Continência, que estáveis no cavaleiro, não tivestes poder contra mim, que estava no rei?». "Continência, disse ainda a Inveja, lembrais como fui grande naquele dia em que um burguês invejou a filha de uma senhora viúva que seu compadre lhe confiou e invejou a horta onde aquela dona vivia com seus filhos? E pela grandeza de minha ação naquele burguês, lembrais que ele corrompeu a filha da senhora viúva e tomou-lhe a horta que tinha?». «Inveja», disse a Continência, «bem sei que sois grande neste mundo, e estais grandemente na ira de Deus. Contudo, ainda que eu seja pouco neste mundo, sou grande na benção de Deus».

- Um mercador tinha mulher e filhos. Ele era um homem comedido e satisfeito com o que Deus tinha-lhe dado. O mercador tinha um asno com o qual ganhava o sustento para viver com seus filhos. O mercador tinha um filho que desejava sua morte, porque tinha inveja daquele asno. Questionou-se onde existia maior grandeza: na continência do mercador ou na inveja de seu filho. ${ }^{6}$

Esse capítulo, embora longo, foi propositalmente transcrito na íntegra e sem interrupções para comentários, para poder ser apreciado o peculiaríssimo estilo do seu autor. Do ponto de vista da psicologia humana e até mesmo da observação sociológica do seu tempo, é sem dúvida digno de nota. Mostra que Llull conhecia bem as pessoas, e os ambientes sociais de sua época, desde o das cortes reais até os da pequena burguesia e do campesinato, sem omitir os ambientes eclesiásticos. A todos conhecia e em todos eles apontava a presença corrosiva da inveja.

\subsection{Llibre de les Bèsties.}

Uma amostra figurativa da vida de corte, que Llull tão bem conheceu e na qual presumivelmente deve ter encontrado não poucos invejosos em sua longa trajetória existencial, é encontrada no opúsculo que

\footnotetext{
5 Como o bispo podia ter inveja de um castelo que já lhe pertencia? E como podia, por inveja, desejar que fosse de outra pessoa, no caso seu sobrinho? A única explicação possível para essa aparente absurdidade é que o castelo pertencia à diocese e o bispo dele tinha somente o usufruto; mas, por inveja, desejava que aquele patrimônio eclesiástico passasse à posse de sua família. Trata-se de uma típica tentação de nepotismo.
}

6 Neste ponto se interrompe o relato. 
escreveu, sob o título Llibre de les Bèsties. Foi ele inserido no corpo do Libre de meravelles, embora já tivesse sido escrito alguns anos antes, como obra autônoma. Trata-se de uma curiosíssima alegoria em que descreve a corte do rei Leão, cercado de animais que representam e simbolizam os vários tipos de áulicos que gravitam nas cortes em torno dos soberanos. Os usos e abusos, os costumes e os vícios, até mesmo as fórmulas de tratamento e cortesia dos palácios reais são graciosamente atribuídos aos personagens figurantes. Nem a pessoa do soberano, com suas fraquezas e quedas morais (por exemplo, o adultério com a bela Dona Leoparda, a mulher do seu leal servidor Leopardo) é poupada. Todos têm seus vícios, suas fraquezas e suas idiossincrasias expostas de modo vivo, em um texto de leitura muito agradável.

A inveja, que tão assiduamente marca presença nas cortes dos grandes da terra, é claro que não podia estar ausente do Llibre de les Bèsties. O elefante conta, a certa altura, a Dona Raposa, uma história acontecida não entre os animais, mas na sociedade dos humanos, de um monarca que tinha dois pajens, um dos quais invejava o outro e foi, por isso, castigado exemplarmente. Um deles, certo dia notou que no manto real, confeccionado com alvíssima seda, ousara pousar uma pulga; aproximou-se com respeito do monarca e, depois de ter pedido sua licença, livrou-o da incômoda companhia do inseto. O rei achou graça no episódio e recompensou o pajem com cem moedas. Outro pajem, com inveja do primeiro, quis repetir o feito e, de propósito, colocou sobre o manto real um enorme piolho, na esperança de que, sendo o piolho bem maior do que a pulga, a recompensa que receberia seria proporcionalmente maior. Mas o tiro lhe saiu pela culatra, pois quando mostrou ao rei o enorme piolho que estava sobre sua vestimenta, o rei se indignou por ele, pajem, ter sido tão desleixado a ponto de não ter antes tirado aquele bicho. E mandou dar-lhe cem chibatadas.

No mesmo opúsculo, são ainda narradas as consequências da inveja da Onça em relação ao Leopardo. Foram ambos os nobres felinos despachados como embaixadores, para visitar o rei dos homens. Levavam, como presentes do rei dos animais para o seu colega humano, o Cão e o Gato, dois animais que os homens muito apreciam. Na corte dos humanos, depois de esperas e aventuras, afinal conseguiram os mensageiros ser admitidos à presença do rei, que os recebeu de modo desigual:

Quando os mensageiros estiveram diante do rei, ele honrou mais o Leopardo que a Onça, dirigindo-lhe um olhar mais prazeroso e fazendo-o sentar mais próximo de si que a Onça. A Onça teve inveja disso e ficou irada com o rei, porque acreditava que ele a devia honrar tanto ou mais que o Leopardo.

As consequências dessa inveja são expostas ao longo de vários capítulos. Enquanto estavam ausentes os dois embaixadores, Dona Raposa, que não gostava do Leopardo, insinuara-se junto ao rei Leão e lhe facilitara o acesso a Dona Leoparda. Encantado com a beleza da felina, o rei a tomou como amante, coisa que logo se espalhou nos mexericos da corte e acabou por chegar aos ouvidos do marido traído. Este, quando tomou conhecimento da traição que lhe fazia o soberano ao qual sempre servira com lealdade, indignouse, acusou-o de traição e o desafiou para um duelo. Um rei, entretanto, somente poderia aceitar combate singular com outro rei, de modo que foi preciso que outro animal representasse, no duelo, a pessoa do rei. Apresentou-se a Onça, movida pela inveja que desde o episódio da audiência com o rei dos homens a atormentava. Fez-se o combate, o Leopardo matou a Onça, mas ficou extenuado com o esforço da luta. Ao final, o rei, traiçoeiramente atacou o Leopardo, que já não teve forças para resistir e morreu. O Leão, porém, também se viu castigado pela vilania que cometera, pois perdeu a sabedoria e a sutileza de espírito, atributos 


\title{
Armando Alexandre dos Santos. O vício capital da inveja na visão de Ramon Llull
}

próprios dos monarcas: «Depois de o Leão ter pecado e matado o Leopardo, não teve mais tanta sutileza nem engenho como tivera antes...».

Todos esses acontecimentos, narrados no mundo da alegoria, não podiam deixar de ser aplicados, no tempo em que foram escritos, a personagens reais, no duplo sentido do termo: reais porque realmente existentes e reais porque se referiam a reis de verdade. A frase com que Llull conclui o Llibre de les Bèsties («Assim acaba o Livro das Bestas, que Félix levou ao Rei»). permitem deduzir que a obra foi dedicada ou entregue pelo autor a um rei de seu tempo. Muito provavelmente foi Filipe IV, rei de França.

\section{As Horas Marianas}

Llull também trata da inveja como um dos pecados capitais em «As horas de Nossa Senhora», pequena obra mariana de caráter lírico, escrita em catalão e composta por estrofes com doze versos cada, próprias para serem entoadas ou cantadas. Cada uma das horas se divide em sete estrofes. A inveja corresponde à estrofe XXXIV e se insere na Hora Nona:

\begin{abstract}
A inveja é o desejo de castelos, mulheres e riquezas, contrariando a caridade e a razão, na medida em que o homem pretende possuir o alheio, ainda que não tendo nenhum direito a ele; por isso a inveja encaminha o homem à ira e à perdição, e jamais [o invejoso] rogará a Nossa Senhora que o ajude; já que o invejoso não possui virtude nem para ser ouvido nem para ser atendido, porquanto seu pecado não pode produzir bem de espécie alguma.
\end{abstract}

\subsection{Llibre Dels Mil Proverbis}

Outra obra em que Llull trata da inveja é o Llibre Dels Mil Proverbis, escrito em 1302. Nele, um dos capítulos trata desse vício capital:

\section{Da Inveja}

1. Através da inveja desejas o que não podes ter.

2. A inveja e a ociosidade são irmãs.

3. A inveja é o maior tormento contra a justiça, a graça e a caridade.

4. Quem tem inveja blasfema a Deus pelo que Ele lhe dá.

5. A inveja deseja ser rica sem bondade.

6. Pela inveja o homem rico e o homem pobre são inimigos.

7. A inveja não dá de graça.

8. A inveja não partilha e deseja ter tudo.

9. Não fales de tuas riquezas com o homem invejoso.

10. O homem invejoso vai com um pé ao orgulho e com o outro à falsidade.

11. Não confies no homem invejoso.

12. O invejoso blasfema o que deseja.

13. O invejoso engana com lágrimas e risos.

14. O invejoso não tem esperança em Deus.

15. O invejoso não deseja a outra vida.

16. A inveja mata sempre o invejoso.

17. O invejoso dá conselho a quem não lhe pede.

18. Não confies teus bens ao invejoso.

19. O invejoso não ama tanto o homem quanto aquilo que o homem ama.

20. O invejoso ama mais o que não tem do que o que tem. 
São provérbios curtos e densos, que revelam a riqueza das observações psicológicas de seu autor. Cada um deles poderia ser comentado, desdobrado e exemplificado ad infinitum. Poderiam constituir títulos para capítulos de uma obra de fôlego, sobre a inveja. Não é necessário nem conveniente nos estendermos sobre eles. As citações aqui feitas são mais do que suficientes para se compreender como Llull concebia a inveja.

\section{Conclusão}

A concepção luliana da inveja em nada contradiz a visão tomista e a tradicional, e seus fundamentos teológicos e filosóficos são os mesmos; mas se mostra muito mais voltada para prática, para a observação concreta dos indivíduos e das situações concretas; e se exprime em linguagem e em estilos adequados a atingir um número muito maior de pessoas, da sociedade leiga, e não apenas estudiosos ou religiosos. Nesse sentido, Llull completa e enriquece extraordinariamente o ensinamento anterior. 


\section{Bibliografia}

\section{Fontes primárias:}

Bíblia Sagrada. Tradução da Vulgata Latina pelo Pe. Matos Soares. São Paulo: Edições Paulinas, 39ª ed., 1982.

Raimondo Lullo (1997) Le ore di Nostra Signora (tradução não versificada: Lino Temperini), in: Caroli, Ernesto (org.) et alii (1997) Mistici Fracescani - Sécolo XIV, Milão, vol. II, p. 537-556.

Raimundo Lúlio (2009) Félix, on O Livro das Maravilhas (tradução: Ricardo da Costa), São Paulo, Editora Escala.

- (2006) Livro das Bestas (tradução: Ricardo da Costa e Grupo de Pesquisas Medievais da UFES I), São Paulo, Editora Escala.

—_. (2007) O Livro dos Mil Provérbios (tradução: Ricardo da Costa), São Paulo, Editora Escala.

Ramon Llull (2010) Árvore da Ciência. Da Árvore Exemplifical (tradução: Ricardo da Costa e Felipe Dias de Souza), Alicante, E-Editorial IVITRA Poliglota. Disponível em: http://www.ivitra.ua.es/RicardoCosta/ Arbor(Ed).pdf - acesso a 22/fev/2018.

- (2010) Doutrina para crianças (tradução: Ricardo da Costa e Grupo de Pesquisas Medievais da UFES III), Alicante, E-Editorial IVITRA Poliglota. Disponível em: http://www.ivitra.ua.es/RicardoCosta/ Llull2.pdf - acesso a 20/fev/2018.

San Francisco de Asís. Escritos. Biografias. Documentos de la época (1993) (edición preparada por José Antonio Guerra), Madrid, Biblioteca de Autores Cristianos.

Sancti Thomae de Aquino opera omnia iussu Leonis XIII P. M. edita (1982), Quaestiones disputatae De Malo (cura et studio Fratrum Praedicatorum), Roma/Paris, Commissio Leonina/Librairie Philosophique J. Vrin, tomus XXIII.

Ss. Gregorius I Magnus (1849) Moralium Libri Sive Expositio in Librum Beati Job, Pars I, Patrologiae Cursus Completus, Série Latina, tomus LXXVI, Paris, J.-P. Migne.

. (1849) Moralium Libri Sive Expositio in Librum Beati Job, Pars Altera, Patrologiae Cursus Completus, Série Latina, tomus LXXVII, Paris, J.-P. Migne.

Santo Tomás de Aquino (1955-1960) Suma Teológica, edição bilíngue latim-castelhano, Madrid, Biblioteca de Autores Cristianos, 16 vol.

\section{Bibliografia complementar:}

Aniz O.P., Candido (1955) Introdução à questão 155 do Tratado da Temperança, in: Suma Teológica de Santo Tomás de Aquino, Madrid, Biblioteca de Autores Cristianos, vol. X.

Pio XI (1928) carta encíclica Rerum Orientalium, disponível em: http://w2.vatican.va/content/pius-xi/it/ encyclicals/documents/hf_p-xi_enc 19280908 rerum-orientalium.html - acesso a 3/set/2016.

Diretório Litúrgico da Conferência da Família Franciscana do Brasil (2016) Brasília, Edição da CFFB.

Gemelli OFM, Agostino (1947) Il Francescanesimo, Milano, Vita e Pensiero. 
Iriarte O.F.M.Cap., Lázaro (1985) História Franciscana, Petrópolis-RJ, CEFEPAL/Editora Vozes.

Le Goff, Jacques (2001) São Francisco de Assis, Rio de Janeiro, Record.

Liturgia das Horas segundo o Rito Romano - próprio para a Família Franciscana Portuguesa (1976) Braga, Editorial Franciscana.

Martyrologium Franciscanum in quo Sancti, Beati, Venerabiles aliique utriusque sexus Servi Dei qui in tribus Ordinibus Minorum, Clarissarum et Poenitentium a Seraphico Patre S. Francisco Assisiensi fundatis aut martyrii, aut sanctitatis, aut miraculorum gloria cunctis nunc usque saeculis claruerunt, singulis anni diebus breviter er ordinate recensentur. (1939) Vicenza, Ex Typographia Commerciali.

Martirologio romano riformato a norma dei decreti del Concilio Ecumenico Vaticano II e promulgato da Papa Giovanni Paolo II (2004) Roma, Libreria Editrice Vaticana.

Merino, José Antonio (1993) Historia de la Filosofía Franciscana, Madrid, Biblioteca de Autores Cristianos.

Roberti, Francesco; Palazzini, Pietro (orgs.) (1957) Diæionario di Teologia Morale, Roma, Editrice Studium.

Santos, Armando Alexandre dos (2018) O vício capital da Inveja, leitmotiv e fio condutor de "Curial e Guelfa»Análise da tradução ao português e estudo cultural e sintático-semântico, tese doutoral disponível em: http://rua. ua.es/dspace/handle $/ 10045 / 88732$ ?locale $=$ en

Ullmann, Reinholdo Aloysio (2000) A Universidade Medieval, Porto Alegre, EDIPUCRS.

Vacant, A.; Mangenot, E.; Amann, É. (1913) Dictionnaire de Théologie Catholique, Paris, Letouzey et Ané.

Vauchez, André (1994) Saint François d'Assise, in: VV. AA. Moines et religieux au Moyen-Age, Paris, Éditions du Seuil, p. 245-263. 